\begin{tabular}{lll} 
KULTURA & $\begin{array}{l}\text { POLSKA A KADEMIA NAUK } \\
\text { KOMITET SOCJOLOGII }\end{array}$ & ISSN 0023-5172 \\
i & $\begin{array}{l}\text { INSTYTUT STUDIÓW POLITYCZNYCH } \\
\text { SPOLECENSTWO nr } 2016, \text { WIDZIANE W MIEŚCIE }\end{array}$ & \\
\hline
\end{tabular}

MARIUSZ BARANOWSKI

Uniwersytet im. Adama Mickiewicza w Poznaniu

\title{
KRYZYS SPOŁECZEŃSTWA KAPITALISTYCZNEGO A (NOWA) KWESTIA MIEJSKA
}

W toku namysłu nad genezą, przebiegiem, a nade wszystko konsekwencjami kryzysu finansowego $z$ lat 2007-2009 francuski socjolog Alain Touraine postawił tezę dotyczącą kryzysu społeczeństwa kapitalistycznego, którą rozwinął wprowadzając pojęcie sytuacji postspołecznej i doszedł do - prowokacyjnej — konkluzji mówiącej o nadejściu w istocie „końca świata społecznego” (Touraine 2013, s. 145-147). Podejmuję tu próbę prześledzenia symptomów owego kryzysu w kontekście kwestii miejskiej, rozumianej jako zbiór (potencjalnych lub faktycznych) konsekwencji organizacji życia społecznego dysfunkcjonalnych wobec indywidualnych i/lub kolektywnych oczekiwań $\mathrm{w}$ ramach sfery miejskiej czy — jak chce Andy Merrifield (2016, s. 4) — tkanki miejskiej. Biorąc pod uwagę rolę, jaką odgrywają — i jak się przewiduje, będą odgrywały w przyszłości - miasta w zglobalizowanym świecie (zob. Dobbs i in. 2012), można potraktować miasto jako „próbkę badawczą” zmian ogólnych (por. Sassen 2000, s. 143-159). Pozwala to zrozumieć ich specyfikę i zaobserwować dynamikę oraz tendencje dotyczące - w tym przypadku — kryzysu społeczeństwa kapitalistycznego. Perspektywa „tego, co miejskie” powinna ponadto umożliwić dostrzeżenie na poziomie mniej abstrakcyjnym niż społeczeństwo globalne cech charakterystycznych mobilizacji społecznej mieszkańców czy procesów „akumulacji przez wywłaszczenie” (Harvey 2003). Horyzont czasowy rozważań będzie wykraczać poza okres ostatniego kryzysu finansowego, gdyż określone przemiany, jakkolwiek zintensyfikowane podczas destabilizacji gospodarki światowej, występowały już dużo wcześniej, co przygotowało grunt 
pod bardziej zasadniczą transformację tkanki miejskiej. Przyjęcie perspektywy społeczności miejskich jest uzasadnione także dlatego, że społeczeństwo jako całość definiowane jest poprzez jego komponenty: wspólne terytorium, wspólną kulturę oraz kolektywną tożsamość, a na poziomie miasta przestrzeń publiczna, konstytuująca realizację określonych wzorów kulturowych, podzielane style życia i poczucie tożsamości, składają się na egzemplifikację szerszego ujęcia „systemu ustrukturowanych relacji społecznych”, jak Anthony Giddens (2007, s. 734) definiuje społeczeństwo.

Problemy lokalnych społeczności i instytucji, określane w socjologii miasta mianem kwestii miejskiej, pozwalają dostrzec nie tylko zanik społecznego spoiwa, ale również zjawiska doń prowadzące, czyli kryzys tego, co publiczne, procesy urynkowienia i prywatyzacji zarówno przestrzeni miejskiej, jak i stosunków społecznych, a także próby kontroli mieszkańców i ruchów społecznych oraz militaryzację przestrzeni (określaną łagodniej mianem „kwestii bezpieczeństwa przestrzeni publicznej"). Procesy te doprowadzają do stanu, który Krzysztof Nawratek (2008, s. 16) określił mianem karykatury Miasta, gdyż to, co pozostało, to raczej „«obszar zurbanizowany» niż Miasto”.

\section{KRYZYS KAPITALIZMU A KRYZYS SPOŁECZEŃSTWA KAPITALISTYCZNEGO}

Frédéric Lordon (2012, s. 122) zwracając uwagę na fakt, iż „żyjemy nie tylko w gospodarce kapitalistycznej, ale też w kapitalistycznym społeczeństwie", podkreślił rolę formacji gospodarczej w kształtowaniu stosunków społecznych. Jakkolwiek struktura zróżnicowania społecznego jest pochodną dominującego sposobu produkcji, to konsekwencje kryzysu mogą przebiegać asymetrycznie i mieć odmienne następstwa w tych dwóch obszarach analizy. Dlatego charakteryzując sytuację po okresie światowej dekoniunktury gospodarczej Alain Touraine (2013, s. 44) stwierdził: „Ostatnie «sukcesy» kapitalizmu finansowego oraz rosnące potrzeby i presje ze strony konsumentów pozwalają mówić o kryzysie społeczeństwa kapitalistycznego (znacznie bardziej niż o kryzysie samego kapitalizmu) w tym sensie, że główni aktorzy tego społeczeństwa zostali zniszczeni (także wówczas gdy jego poziom gospodarczego funkcjonowania zdaje się w miarę zadowalający)".

Teza na temat nieuchronności kryzysu w kapitalizmie pojawiła się co najmniej w czasach opublikowania Kapitatu Karola Marksa (zob. Harman 2011, s. 86-91) i nadal jest aktualna (por. Harvey 2014), ale z perspektywy socjologicznej kwestią o wiele istotniejszą są konsekwencje społeczne recesji gospodarczych. Problem ten zostanie podjęty w kontekście przestrzeni miejskiej, gdyż — jak wiele lat temu zauważył Manuel Castells (1982, s. 135) — „analiza przestrzeni jako sposobu wyrażania się struktury społecznej sprowadza się [...] do badania sposobu jej kształtowania przez elementy systemu ekonomicznego, politycznego i ideologicznego". Z kolei Thomas Gieryn (2000, s. 482) posługiwał się określeniem a place-sensitive sociology, by zwrócić uwagę na znaczenie 
miejsca w analizach nierówności, władzy, polityki, pamięci, ruchów społecznych, przestępczości, tożsamości itp.

Alain Touraine (2013, s. 48-49) utrzymywał: „kapitalizm przeszedł poważny kryzys, ale trudno uznać, aby wyszedł z niego specjalnie osłabiony. Można nawet powiedzieć, że to właśnie kapitalizm finansowy potrafił jako pierwszy podnieść się z głębokiego upadku”. Stwierdził także, co istotniejsze, że „najbardziej dramatycznym aspektem schyłku kapitalizmu jest rosnąca słabość aktorów społeczno-ekonomicznych oraz zdolność interwencji ze strony państwa" (Touraine 2013, s. 51). Tym uwarunkowaniom oraz mechanizmom je odzwierciedlającym na poziomie problemów miejskich (zob. Pløger 2010; Jones 2009; May i in. 2005; Walton 1993; Downs 1961) poświęcone są poniższe rozważania. Warto przy tym zaznaczyć ważną rolę tzw. struktur pośredniczących w kształtowaniu społeczeństwa kapitalistycznego. Odegrały one istotną rolę w aktywizacji społecznej w toku konstytuowania i rozkwitu kapitalistycznych gospodarek, a były to w istocie nowoczesne instytucje, takie jak „zorganizowane grupy interesu, spółdzielnie, związki zawodowe, wszelkiego rodzaju korporacje i dobrowolne stowarzyszenia o zasięgu lokalnym czy regionalnym" (Berger 1995, s. 157). To te instytucje w czasach dynamicznego rozwoju kapitalizmu przemysłowego stanowiły o aktywności społeczeństwa i pośredniczyły — twierdzi Peter L. Berger - między jednostkami a szerszym społeczeństwem (z takimi wielkimi instytucjami jak gospodarka i państwo włącznie), stąd określenie mediating structures.

$\mathrm{Na}$ obecnym etapie rozwoju kapitalizmu nie wykształciły się jeszcze nowe formy organizacji społecznej, stanowiące rzeczywistą przeciwwagę dla interesów wielkich korporacji, banków i firm finansowych. Poziom analizy socjologii miasta pozwala dostrzec te destrukcyjne dla społeczeństwa tendencje, a także — gwoli ścisłości — rozmaite próby samoorganizacji społecznej. Niemniej jednak dostrzeżenie i nagłośnienie istotnych aktualnie problemów i kwestii miejskich nie oznacza mobilizacji szerokich mas przeciw ich negatywnym skutkom.

\section{SZEROKIE BULWARY I WAৃSKIE MOSTY W PRZESTRZENI PUBLICZNEJ}

Pojęcie przestrzeni publicznej odniesione do problematyki miejskiej wykracza poza z jednej strony wąsko rozumiany obszar geograficzny, a z drugiej dyskursywnie zdefiniowaną sferę publiczną. Zawierając komponent fizykalnie pojmowanego miejsca, jak również odnosząc się do różnych form komunikacji wyrażonych w języku, pojęcie to obejmuje „wszelkie przestrzenie służące podtrzymywaniu więzi społecznych oraz wzorów kultury, nie ograniczając przedmiotu zainteresowania wyłącznie do kwestii formowania się opinii publicznej oraz woli politycznej" (Baranowski, Cichocki 2016).

Takie rozumienie przestrzeni publicznej, którą można określić także jako przestrzeń społeczną (por. Kuryłowicz 2008, s. 39-40), pozwala spojrzeć na miasto zarówno od strony zabudowy architektonicznej, a zwłaszcza funkcjonal- 
ności i dysfunkcjonalności obiektów miejskich i ich lokalizacji, jak i od strony wspólnotowego, relacjotwórczego potencjału owej przestrzeni, włącznie z „zaangażowaniem obywatelskim" (Tittenbrun 2014, s. 15), często określanym nieprecyzyjnym terminem kapitału społecznego. Te dwa wymiary warunkują się wzajemnie i dlatego architektura „poza tym, że jest sztuką kształtowania przestrzeni, jest też sztuką dialogu oraz komunikowania znaczeń i emocji [...] [a] obecne jej formy, choć dostarczają wrażeń, wynikających z operowania formalnymi zabiegami technologicznymi, pozbawione są często kontekstu miejsca, kontynuacji, nawiązania do istniejącej tkanki miejskiej" (Dymnicka 2011, s. 87).

Strategia kształtowania i wpływania na przestrzeń miejską może przyjmować rozmaite formy, ale wtedy gdy jest intencjonalnie wdrażana, służy realizacji określonego, odpowiadającego założonym wytycznym, scenariusza zmiany (nie zawsze funkcjonalnego dla społeczności). Weźmy przykłady Paryża i Nowego Jorku.

Analiza kształtowania struktury przestrzennej całego regionu paryskiego, opisana przez Castellsa (1982, s. 42-52), ukazuje przebieg procesów industrializacji w bardzo szerokim kontekście historycznych i politycznych uwarunkowań położenia stolicy Francji wobec innych ośrodków. Jednak by uwypuklić wspomniane wyżej odmienne scenariusze zmian, ograniczę się do jednego $z$ aspektów procesu haussmannizacji, czyli praktyki „dzielenia i rządzenia, klasowego wysiedlania dokonywanego środkami przestrzennej transformacji, społecznej polaryzacji realizowanej w drodze politycznych i ekonomicznych manipulacji" (Merrifield 2016, s. 51).

Strategia przebudowy Paryża, której pomysłodawcą był Georges Haussmann, obok waloru czysto technicznego, to jest realizacji systematycznego i zakrojonego na szeroką skalę projektu urbanistycznego, który zmienił miasto między innymi przez budowę szerokich bulwarów kosztem wyburzenia historycznych zabudowań (czemu towarzyszyły wysiedlenia, głównie rodzin robotniczych), służyła również celom o charakterze polityczno-społecznym. Miała utrudnić organizację barykad na wypadek buntów czy zamieszek społecznych (Marks 1949), a także skrócić drogę wojska z koszar do miejsc konfliktowych.

Po drugiej stronie Atlantyku Robert Moses, odpowiedzialny za planowanie przestrzenne Nowego Jorku, realizował analogiczne do haussmannowskich wizje, tyle że za pomocą innych narzędzi. „Powszechnie znany jest przykład nowojorskich mostów jego autorstwa, które zaprojektował w taki sposób, by nie mogły po nich jeździć autobusy. W efekcie ograniczona została mobilność wybranych kategorii społecznych — przede wszystkim Afroamerykanów korzystających głównie z komunikacji publicznej - i ich dostęp do atrakcyjnych przestrzeni publicznych" (Afeltowicz, Pietrowicz 2013, s. 27).

$\mathrm{Z}$ punktu widzenia kształtowania przestrzeni miejskiej oba przedsięwzięcia oprócz funkcji jawnych, dotyczących architektonicznych zmian urban fabric, spełniały funkcje ukryte, daleko wykraczające poza rozwiązania czysto prak- 
tyczne. W istocie były to projekty inżynierii społecznej, które za pomocą rozwiązań architektonicznych w określony i przemyślany sposób kształtowały stosunki społeczne. Przykłady wysiedlania obszarów zamieszkanych przez przedstawicieli niektórych klas społecznych lub określanych mianem „złych dzielnic” (Wacquant 2009, s. 25) bądź utrudnianie przemieszczania się w obrębie miasta mieszkańcom o niskim statusie materialnym dowodzą, jak plany zagospodarowania przestrzennego mogą być wykorzystywane do realizacji wizji społecznej strukturyzacji na poziomie wyższym od szczebla miejskiego. Procesy suburbanizacji w Stanach Zjednoczonych, jako jedna z konsekwencji transformacji przestrzeni miejskiej, nie tylko skutkowały segregacją mniejszości rasowych czy grup zagrożonych wykluczeniem społecznym, ale również doprowadziły do „radykalnej transformacji stylu życia ze wszystkimi jej społecznymi konsekwencjami" (Harvey 2012a, s. 29).

W nawiązaniu do zmian dziewiętnastowiecznego Paryża opisywanego przez Waltera Benjamina autor Nowej kwestii miejskiej, charakteryzując współczesne transformacje i powiązania między poziomem systemu gospodarczego a miastem, stwierdził: „Machinacje biznesowe stały się [...] machinacjami w przestrzeni miejskiej, finansowaną przez państwo promocją rynku nieruchomości, inwestycjami polegającymi na konfigurowaniu nowej i wywłaszczaniu starej przestrzeni. Diabelski pakt między polityką i ekonomią podlegał tym samym swojej nowoczesnej konsekracji" (Merrifield 2016, s. 62).

\section{NOWE CZASY I NOWE GRODZENIA}

Zamknięte enklawy, na przykład w postaci grodzonych osiedli (gated communities), nie tylko nie przyczyniają się do budowania zaufania czy porozumienia społecznego, lecz przeciwnie wpływają na ukształtowanie się sytuacji nieufności czy potencjalnych napięć między członkami danej społeczności (por. Odrowąż-Coates 2015, s. 233-249). Rozważając ten, jakże popularny w Polsce, typ osiedli z perspektywy kryzysu społeczeństwa kapitalistycznego, warto mieć na względzie, że pojawienie się tego typu zabudowy „spowodowało powstanie wyraźnej granicy między tym, co publiczne, a tym, co prywatne (chodnik przy prywatnym obiekcie jest równy, dobrze oświetlony, a zieleń zadbana, porządku pilnuje ochrona)” (Tobiasz-Lis 2011, s. 112). Co więcej: „obok dezintegracji o charakterze przestrzennym, zjawisku towarzyszą negatywne procesy w sferze społecznej miast - powstawanie podziałów społecznych, konfliktów, osłabienie więzi społecznych" (Tobiasz-Lis 2011, s. 112).

Coraz częstsze grodzenie osiedli, bardzo mocno związane $z$ potrzebą poczucia bezpieczeństwa (odczuwaną głównie przez przedstawicieli nowej „klasy" metropolitalnej), wzmacnianą treściami przekazów medialnych na temat przemocy $w$ mieście, wiąże się z bardziej ogólną tendencją do urynkowienia bezpieczeństwa. Prowadzi to do zaistnienia mechanizmu w socjologii określanego jako problem zbiorowego działania, przyjmujący niekiedy postać wyścigu 
na dno (race to the bottom) (zob. Heath, Potter 2010, s. 87-124), co w tym przypadku oznacza wyższy poziom deprywacji po stronie tych, którzy konstytuują tzw. klasy ludowe (Wacquant 2009), a osobom wystarczająco zamożnym, by posiadać mieszkania lub domy w grodzonych dzielnicach, pozostawia jedynie poczucie bezpieczeństwa (sugestywnie wzmacniane wyższymi płotami, większą liczbą kamer czy ochroniarzy, nawet z psami). Można - za Jackiem Tittenbrunem (2014, s. 154) — pokusić się o jeszcze dalej idące wnioski: „Urynkowienie bezpieczeństwa to dramatyczny przykład szerszego trendu w stronę prywatyzacji życia. Prywatni funkcjonariusze patrolujący tereny amerykańskich osiedli i firm już na początku lat siedemdziesiątych przewyższyli liczebnie policję publiczną".

Ta jawna dysproporcja między sektorem publicznym - nawet przez neoliberalnie zorientowanych ekonomistów, jak Milton Friedman, utożsamianym $z$ funkcją utrzymywania bezpieczeństwa i porządku, również $\mathrm{w}$ warstwie semantycznej, „publicznego" - a sektorem prywatnym, zarezerwowanym dla „pełnych” konsumentów (w przeciwieństwie do „wybrakowanego konsumenta" Zygmunta Baumana; 2006, s. 18), ma szerokie konsekwencje dla całości stosunków społecznych w czasach rozwiniętego kapitalizmu:

„[...] wśród przynależnych państwu funkcji, które podlegają prywatyzacji, są nie tylko zaopatrzenie w publiczne dobra i usługi, takie jak elektryczność czy obsługa lotnisk, lecz i działania dotychczas uważane za rdzennie publiczne, jak więzienia i utrzymywanie porządku publicznego oraz troska o bezpieczeństwo obywateli. Ba, nawet formułowanie polityki zleca się prywatnym agencjom — konsultantom, prywatnym instytutom, think tankom [...]" (Tittenbrun 2014, s. 155).

Z perspektywy szeroko zakrojonych mechanizmów prywatyzacyjnych sposoby przeciwdziałania grodzeniu przestrzeni miejskiej w postaci programu „secure by design, opartego na teorii defensible space O. Newmana, którego podstawowym założeniem jest takie aranżowanie przestrzeni w fazie projektu, aby była przestrzenią bezpieczną" (Tobiasz-Lis 2011, s. 112), wydają się propozycjami tyleż ciekawymi koncepcyjnie (zob. Zaborska 2007, s. 113-119), co mało istotnymi w obliczu generalnych tendencji indywidualistycznych, które rozrywają miejską tkankę społeczną. Potwierdza to Zygmunt Bauman (2012, s. 78-79), wyjaśniając powody, dla których ludzie kupują bądź wynajmują mieszkania w „grodzonych wspólnotach/społecznościach”: „Nawet jeśli ludzie mówią (a czasami myślą) co innego, to te ciężkie pieniądze wydają po to, by «uwolnić się" od niechcianego towarzystwa, by kupić sobie "święty spokój». Za tymi murami i bramami żyją samotnicy: ludzie tolerujący tylko taką "Wspólnotę", która akurat im konweniuje, i tylko wówczas, gdy im konweniuje". A w konsekwencji praktyka grodzenia „dzieli mieszkańców miasta na «lepszych» i «gorszych", ponieważ rozrywa i pochłania przestrzeń publiczną należącą do wszystkich obywateli miasta [oraz] niszczy miejską różnorodność i przyczynia się do wychowania młodego pokolenia o mentalności ludzi «getta», niezależnie od te- 
go, czy będzie to getto bogatych, czy biednych" (Jałowiecki, Łukowski 2007, s. 9-10). Ta forma segregacji przestrzenno-społecznej wraz z tzw. urban sprawl, czyli procesem suburbanizacji, przenoszenia się na przedmieścia (Nawratek 2008, s. 15), nie prowadzi do obalania stereotypów i szukania porozumienia, co skutkowałyby powstaniem relacji społecznych o nowej jakości. Powoduje raczej „powrót do struktury plemiennej [...w której] strach przed bezosobowym życiem, waga, jaką się przywiązuje do intymnych kontaktów, sprawiają, że tak zwana cywilizowana egzystencja, czyli taka, w której ludzie mogą się cieszyć różnorodnymi doświadczeniami, stała się przywilejem bogatych i dobrze urodzonych" (Sennett 2009, s. 548).

\section{RUCHY SPOŁECZNE I ANTYSPOŁECZNE PRZESTRZENIE MIEJSKIE}

Mówiąc o kryzysie społeczeństwa kapitalistycznego i kwestii miejskiej nie sposób abstrahować od ruchów społecznych. Alain Touraine przeciwstawia „społeczeństwa konfliktu” „społeczeństwom ruchów społecznych”, te pierwsze rozumiejąc jako „społeczeństwa zamknięte w sobie, jak niektóre wiejskie wspólnoty typu śródziemnomorskiego czy «dzielnice» lub "getta», które rozwinęły się w centrach miast i na peryferiach aglomeracji" (Touraine 2011, s. 195). To one stanowią przykład kryzysu wspólnoty w czasach rozwiniętego kapitalizmu, ponieważ „zdominowane są przez biedę, bezrobocie i dyskryminację” oraz pozbawione "jakiejkolwiek jednoczącej siły". Siłę taką mają ruchy społeczne, ale i one napotykają problemy związane z przestrzenią miejską i postępującymi procesami jej prywatyzacji.

O tym, w jaki sposób „kurczy się” miejska przestrzeń publiczna, a zatem także możliwość mobilizacji społecznej, która jest mocno zakorzeniona w obszarze geograficznym, niech świadczą przykłady ruchów społecznych powstałych na kanwie ostatniego kryzysu finansowego i szerszych autorytarnych tendencji w krajach arabskich.

Niezależnie od przyczyn inicjujących tzw. Arabską Wiosnę Ludów, ruch oburzonych (Movimiento 15-M) czy ruchy typu Occupy Wall Street (Occupy Together) dla wszystkich tych form mobilizacji społecznej, obok wykorzystywania nowych technologii sieciowych do organizowania się i koordynacji swoich działań, charakterystyczny jest związek z przestrzeniami miejskimi, zwłaszcza z placami. Maidan Tahrir w Kairze, Puerta del Sol w Madrycie, Plac Syntagma w Atenach, Plac Republiki w Rzymie, Zuccotti Park w Nowym Jorku oraz Paternoster Square w Londynie były bowiem symbolami tych oddolnych zrywów i aktywizacji obywatelskich.

Jak zauważył brytyjski geograf i teoretyk miasta David Harvey (2012b): „Ruch Occupy Wall Street został zapoczątkowany na terenie prywatnym, w Zuccotti Park. W Londynie Paternoster Square, uważany powszechnie za miejsce publiczne, tak naprawdę zarządzany jest przez prywatną firmę - i dlatego protestujący w tym mieście musieli się przenieść na schody katedry Świę- 
tego Pawła. Nie ma tam przestrzeni publicznej". Trudno nie powiązać tej obserwacji z bardziej generalną tendencją do ograniczania praw i wolności konstytucyjnych w imię bezpieczeństwa i porządku publicznego, co często ma charakter prewencyjny, czyli de facto zostaje wyłączone ze standardowej procedury kontroli przez inne instytucje. Gdy do tych praktyk (na przykład w imię „walki z terroryzmem") dołączymy procedery prywatyzacji przestrzeni publicznej w miastach, jak również procesy gentryfikacji, to jest „transformacji robotniczych lub opuszczonych obszarów umiejscowionych w centrach miast w dzielnice mieszkaniowe klasy średniej i/lub o komercyjnym znaczeniu" (Lees, Slater, Wyly 2008, s. XV), reprywatyzację (Osajda 2009) i generalną promocję konsumpcjonizmu, to wyraźnie dostrzeżemy solidne podstawy kryzysu społeczeństwa.

Do kluczowych właściwości ruchów społecznych Piotr Sztompka (2005, s. 271) zaliczył potencjał morfogenetyczny, czyli „skuteczność we wprowadzaniu strukturalnych przekształceń". Jeden $z$ powodów wzrostu ich znaczenia w kształtowaniu rzeczywistości społecznej - określony jako „temat Durkheima" (Sztompka 2005, s. 259) - ma związek z procesami urbanizacji i industrializacji, które przyczyniły się do „fizycznego skupienia się wielkich mas ludzi na niewielkim obszarze, co wytworzyło wysoką "gęstość moralną" populacji”, stwarzając „lepsze możliwości do nawiązywania kontaktów i interakcji, formułowania zbiorowych poglądów, artykułowania wspólnych ideologii i werbowania zwolenników" (Sztompka 2005, s. 259-260).

Skuteczność ruchów społecznych może zostać znacząco zmniejszona przez redukcję warunków sprzyjających ich powstawaniu. Negatywny wpływ na oddolne formy mobilizacji społecznej mają współcześnie obserwowane praktyki ograniczania przestrzeni publicznej oraz wolności słowa i zgromadzeń (np. polska ustawa „Prawo o zgromadzeniach” z 2015 roku), czemu towarzyszy wzmocnienie mechanizmu penalizacji. Jednak równocześnie owe praktyki przyczyniają się do powstania nowych form oporu, opartych na odmiennej strategii działania. Nowe ruchy społeczne - jak stwierdził Pierre Rosanvallon (2011, s. 52) — „w odróżnieniu od dawnych ruchów społecznych, w tym emblematycznych już związków zawodowych, nie chcą pełnić funkcji przedstawiciela czy strony w negocjacjach społecznych. Ich celem jest uwypuklenie problemów i sprzeciw wobec władz, a nie reprezentowanie społeczeństwa".

Obok whistleblowers, czyli osób lub grup, „które odgrywają aktywną rolę w sygnalizowaniu problemów w obszarze swojego funkcjonowania" (Rosanvallon 2011, s. 50), pojawia się wiele inicjatyw mających na celu „odzyskiwanie” miasta, między innymi przez organizowanie pomocy eksmitowanym na skutek procesów gentryfikacji, alternatywne formy wymiany czy nawet tzw. codzienny urbanizm, czyli „podejmowane przez mieszkańców wielkich miast próby przekształcenia ich przestrzeni, które nie mają charakteru manifestacji poglądów, tak jak graffiti, czy szerzej street art, ale są raczej próbami dostosowania miejsca życia jednostki do jej potrzeb, czasowości, gustów i upodobań" (Krajewski 2010, s. 47). 
Inicjatywy te przeciwstawiają się zindywidualizowanemu społeczeństwu, zakusom zawłaszczania terenu i konkretnych lokali (tzw. czyściciele kamienic), wypracowują barterowe formy handlu, animują międzysąsiedzkie relacje (Q-Ruch Sąsiedzki) i wpływają na kształt małej architektury. W niektórych przypadkach są bardzo skuteczne i ich rozwiązania są przeszczepiane do innych ośrodków. Problem polega na tym, że nie są zintegrowane i nie kreują jednolitego programu (a)politycznej zmiany, która zyskałaby szerokie poparcie i wtórnie oddziaływała na instytucjonalny wymiar życia miejskiego, a w konsekwencji społecznego w ogóle.

\section{OTO NADCHODZI KAŻDY (WRAZ Z MILITARYZACJĄ PRZESTRZENI MIEJSKIEJ)}

Loïc Wacquant w Więzieniach nędzy (2009, s. 47) pisał o „zastąpieniu «matczynego" państwa opiekuńczego, "paternalistycznym» państwem karzącym", ponieważ „tylko ono będzie w stanie narzucić miejsca pracy bez standardów socjalnych jako społeczną normę i dać podstawę do nowego spolaryzowanego ładu klasowego". Ów ład zaś jest odpowiedzialny za "nowy typ obywatelstwa”, który Andy Merrifield (2016, s. 25-26) rozumie jako: „miejskie obywatelstwo pracowników bez pracy najemnej, studentów bez karier (pokolenie NINJA «No Income, No Jobs and Assets» — «Bez dochodu, pracy i aktywów»), biednych i klasy średnie bez mieszkań, emerytów bez emerytur - Oto Nadchodzi Każdy (HCE — «Here Comes Everybody»)".

Upowszechnienie - już od ponad trzech dekad - ekonomicznych polityk neoliberalnych, kształtujących społeczeństwa kapitalistyczne nie tylko w najbardziej rozwiniętych krajach, ma wiele negatywnych konsekwencji społecznych. Autor Nowej kwestii miejskiej mówi o neohaussmannizacji, czyli „globalnej strategii miejskiej, która dokonuje peryferyzacji milionów ludzi na całym świecie, a robi to na taką skalę, że traci sens opisywanie tych ludzi jako peryferyjnych" (Merrifield 2016, s. 52). W wyniku tego dochodzi do rozmycia intersubiektywnie komunikowalnych podziałów, które do niedawna strukturyzowały nasze myślenie o nierównościach socjoekonomicznych. Można nawet mówić o „patchworkowej kołdrze społeczno-przestrzennego oraz rasowego apartheidu, która rozciąga się od Paryża po Palestynę, od Londynu po Rio de Janeiro, od Johannesburga po Nowy Jork" (Merrifield 2016, s. 52). Dlatego Merrifield (2016, s. 56) nazywa kapitalizm finansowy, którym to określeniem posługuje się Touraine, „pasożytniczym kapitalizmem”. Nieważne, jaką nazwę przyjmiemy - a możemy posłużyć się także propozycją Michela Hussona (2011): „kapitalizm bez znieczulenia” — konsekwencją tego systemu globalnej akumulacji kapitału jest kryzys społeczeństwa. „Nadszedł wreszcie czas — pisze Wacquant (2009, s. 71) - aby rozszerzyć ten [neoliberalny - M.B.] porządek tak, aby objął również represywną politykę bezpieczeństwa i penalne traktowanie społecznych marginesów" (w polskim kontekście zob. Galor $\mathrm{i}$ in. 2014). 
Zagadnienie militaryzacji miejskich przestrzeni daleko wykracza poza kontrolę kategorii underclass, co w sposób bardziej wyrafinowany określa się jako „kwestię dynamiki procesów koncentracji przestrzennej grup zmarginalizowanych" (Sałustowicz 2008, s. 181). Problemy osób zmarginalizowanych lub zagrożonych marginalizacją mają bezpośredni związek z organizacją przestrzeni miasta $\mathrm{i}$ jej pochodną $\mathrm{w}$ postaci rozwarstwienia społecznego, co przyjmuje formę działania tzw. diabelskiego koła: „Złe warunki mieszkaniowe, niewystarczająca infrastruktura, negatywne etykietki dla dzielnicy jako "zły adres», brak pozytywnych, tj. wspomagających integrację wzorów dla małoletnich, brak przestrzennego dostosowania (space mismatch) między lokalizacją getta a lokalizacją dostępnych dla jego mieszkańców miejsc pracy w przemyśle, niestabilność sieci społecznych i powszechność przemocy oddziałują między sobą i wzmacniają się" (Häußermann i in. 2004, s. 26; cyt. za Sałustowicz 2008, s. 181).

Przyjrzyjmy się przykładowi intencjonalnej próby utrudnienia stosunków społecznych pracownikom zakładów produkcyjnych (czyli nie osobom z tzw. marginesu), co miało związek z usytuowaniem przestrzennym ich miejsca pracy. Opisując organizację pracy w Tarnobrzeskiej Specjalnej Strefie Ekonomicznej Jarosław Urbański (2014, s. 211), na podstawie relacji byłego pracownika firmy-podwykonawcy LG, dostrzegł, że „[...] usytuowanie kolejnych fabryk w zasadzie uniemożliwia jakiekolwiek porozumienie się między pracownikami. Są przywożeni i odwożeni z zakładowych, odseparowanych od siebie parkingów". Przestrzenny plan zabudowy kompleksu przemysłowego określa zatem możliwości komunikacji zatrudnionych tam osób. Z perspektywy świata kapitału ma to określone znaczenie - uniemożliwia porozumiewanie się pracowników ze sobą, blokuje jakiekolwiek formy kooperacji, z wymianą informacji czy zorganizowaniem się w związki zawodowe włącznie. Gdy dodamy takie czynniki jak rozproszenie przestrzenne miejsc zamieszkania pracobiorców, często zatrudnionych poprzez agencje pracy tymczasowej lub za płacę minimalną, oraz czas transportu $z$ fabryki do domów, to jedność świata pracy okazuje się bardzo utrudniona.

Bardziej konsekwentny charakter ma militaryzacja przestrzeni publicznej $\mathrm{w}$ miastach, która $\mathrm{w}$ istocie za pomocą nowych technologii wkracza $\mathrm{w}$ sferę prywatną życia mieszkańców (Baranowski, Luczys 2015). Weźmy przykład Londynu, w którym dzielnice finansowe stanowią wyśmienitą ilustrację militaryzacji przestrzeni miejskiej. Ulice i place śródmiejskiej dzielnicy City „już od początku lat 90. [ubiegłego wieku - M.B.] są kontrolowane i monitorowane przez jeden $z$ największych i najbardziej zaawansowanych na świecie antyterrorystycznych systemów zabezpieczeń i nadzoru wizyjnego, tak zwany «stalowy pierścień»". Polega to na tym, że „londyńskie ulice zostały przegrodzone stalowymi słupkami, a pasy dojazdowe do punktów kontrolnych oznakowane plastykowymi pachołkami. Z czasem system ten nazwany został - Ring of Plastic - "plastikowy pierścień", jednak obecność środków ochrony i kontroli 
policyjnej była nadal powszechnie odczuwalna". Wszystkie te zabezpieczenia wspierane są stałym monitoringiem kamer (CCTV), Eksperymentalną Organizacją Ruchu (Experimental Traffic Scheme) oraz systemem ANPR (Automatic Number Plate Recording), który ,jest w stanie automatycznie zarejestrować wszystkie tablice rejestracyjne samochodów wjeżdżających do City, w ciągu 4 sekund rozpoznać podejrzane numery i dać zwrotny sygnał do posterunków kontrolnych" (Jasiński 2009, s. 326).

City nie stanowi w Londynie wyjątku. Własną strefę ochrony, zwaną Iron Collar, ma biznesowa dzielnica Canary Wharf, a specjalne środki fortyfikacji obejmują także ambasadę Stanów Zjednoczonych, budynki rządowe czy tzw. nie-miejsca, to jest „nowoczesne przestrzenie konsumpcji i transportu: galerie i centra handlowe, wielkie sklepy, restauracje, atria hotelowe, a także dworce kolejowe i lotnicze, gdzie przebywający podlegają segregacji $\mathrm{w}$ bardzo szczególny sposób, są obserwowani i kontrolowani" (Jasiński 2009, s. 328).

Przykłady można mnożyć, odwołując się do wielkich i mniejszych miast, do krajów rozwiniętych i mniej zaawansowanych gospodarczo (zob. Davis 2009, 1990). Militaryzacja przestrzeni miejskiej w imię walki z terroryzmem czy z przestępcami lub osobami z marginesu, ze slumsów, faveli, banlieues czy innych „wrażliwych dzielnic” jest faktem. Podobnie, jak faktem jest to że owe „antyterrorystyczne środki planistyczne i techniczne, mające zapewnić bezpieczeństwo miastom i ich mieszkańcom, przynoszą w efekcie militaryzację i fortyfikację przestrzeni miejskich, a policyjne metody walki z terroryzmem mogą skutkować naruszaniem praw i swobód obywatelskich" (Jasiński 2009, s. 334-335). Godzi to w „istotę miasta jako wolnej publicznej przestrzeni” i może doprowadzić do „większych społecznych, psychologicznych i przestrzennych zniszczeń niż sam terroryzm" (Jasiński 2009, s. 335).

Związek między kwestią miejską a kryzysem społeczeństwa kapitalistycznego jest ściślejszy, niż mogłoby się wydawać na pierwszy rzut oka. Andy Merrifield, przywołując słowa Raya Pahla z Whose City? („miasto jest tym, na co pozwala mu społeczeństwo”), sugestywnie uwidocznił to połączenie: „dialektyka między miastem i społeczeństwem — dodał — nigdy nie będzie już taka sama" (Merrifield 2016, s. 150).

Współczesne państwa stosują strategię „«rządzenia przez zaciskanie pasa» [austerity governance], przez «rządy księgowych» [rule by accountacy]. Równoważenie miejskich i federalnych ksiąg okupowane jest w tym kontekście sprzedażą «rodowych skarbów», prywatyzacją publicznych aktywów, outsourcingiem publicznych usług oraz oddawaniem lub wyprzedażą ziemi po znacznie zaniżonych cenach" (Merrifield 2016, s. 47). Wszystkie te konsekwencje, łącznie $z$ następstwami przemian globalnych, są odczuwane przez członków społeczeństwa przede wszystkim na poziomie miasta, stanowiącego swoistą „ojczyznę 
prywatną" (Ossowski 1967), w której jesteśmy na co dzień zakorzenieni. Dlatego ograniczanie przestrzeni publicznej dostępnej dla każdego, ale też służącej do manifestacji niezadowolenia społecznego, staje się elementem konstytutywnym kryzysu nie tylko społeczności lokalnych, lecz również społeczeństwa jako całości.

Wspomniana polityka austerity (zob. także Donald i in. 2014), grodzenie przestrzeni oraz tendencje do militaryzacji i penalizacji - wszystko to przyczynia się do zaniku oddolnych inicjatyw, będących podstawą podmiotowości całych społeczności. Neoliberalna odmiana kapitalizmu, która w olbrzymim stopniu kształtuje (kapitalistyczne) społeczeństwo, coraz bardziej zindywidualizowane oraz utowarowione, ma społeczne reperkusje w postaci albo pasywności, albo partykularnych strategii funkcjonowania w imieniu wąsko rozumianej grupy. A przecież, jak twierdził Touraine (2010, s. 114), „społeczeństw nie określa ich funkcjonowanie, lecz zdolność do przekształceń”, która systematycznie jest eliminowana na poziomie tkanki miejskiej i rozlicznych strategii prywatyzowania zysków oraz uspołeczniania strat. Nowe kwestie społeczne są zatem następstwami ogólnych tendencji gospodarczych albo - jak chce David Harvey (2012a, s. 101) — oznaczają „dominację klasy kapitalistycznej nie tylko nad aparatem państwowym (w szczególności nad tymi aspektami władzy państwowej, które administrują i zarządzają społecznymi i infrastrukturalnymi warunkami w ramach struktur terytorialnych), ale także nad całymi populacjami - ich stylami życia, jak i ich siłą roboczą, kulturowymi i politycznymi wartościami oraz myślowymi koncepcjami świata".

Kryzys współczesnego społeczeństwa kapitalistycznego, które okazało swoją słabość w obliczu ostatniego załamania finansowego, jest konsekwencją wielu czynników makro-, mezzo- i mikrostrukturalnych. Perspektywa miasta pozwala prześledzić wpływ tych determinant zarówno na społeczności najsłabsze (doznające wykluczenia społecznego, spychane do gett miejskich i sfery gospodarki nieformalnej), jak i najsilniejsze (skrywające się za murami chronionych osiedli, w asyście prywatnych firm ochroniarskich, specjalnych stref bezpieczeństwa w dzielnicach finansowych itp.). Rozpoznanie i nazwanie tendencji ograniczających podmiotowość społeczeństwa, które wyraźnie uwidoczniają się na poziomie miast między innymi poprzez redukowanie przestrzeni publicznej i jej militaryzację, kontrolowanie oddolnych inicjatyw obywatelskich, postępujące procesy prywatyzacji i urynkowienia właściwie każdego aspektu życia społecznego, stanowi element teoretycznej kontrofensywy. Przez uświadamienie sobie zróżnicowanych przyczyn postępującej apatii społecznej, de facto opisywanej od dawna (np. Bell 1998; Putnam 2008), oraz lokalizację jej źródła na poziomie miasta można zacząć przynajmniej koncepcyjnie wypracowywać wielowymiarowy i wieloośrodkowy program odzyskiwania podmiotowości społecznej, począwszy od poszczególnych ulic, placów, dzielnic (tzw. architektura miastotwórcza), które należy postrzegać jako istotne elementy większej całości (emancypacji i wspólnotowości). 


\section{BIBLIOGRAFIA}

Afeltowicz Łukasz, Pietrowicz Krzysztof, 2013, Maszyny społeczne. Wszystko ujdzie, o ile działa, Wydawnictwo Naukowe PWN, Warszawa.

Baranowski Mariusz, Cichocki Piotr, 2016, Przestrzeń publiczna i państwo dobrobytu. Wprowadzenie, w: Mariusz Baranowski i in. (red.), Przestrzeń publiczna i państwo dobrobytu, Wydawnictwo Naukowe WNS UAM, Poznań.

Baranowski Mariusz, Luczys Piotr, 2015, Nadzorować i kształtować. Wymiary społeczeństwa sieciowego, „Człowiek i Społeczeństwo”, t. XL, s. 13-27.

Bauman Zygmunt, 2006, Praca, konsumpcjonizm i nowi ubodzy, tłum. Stanisław Obirek, Wydawnictwo WAM, Kraków.

Bauman Zygmunt, 2012, Straty uboczne. Nierówności społeczne w epoce globalizacji, tłum. Justyn Hunia, Wydawnictwo Uniwersytetu Jagiellońskiego, Kraków.

Bell Daniel, 1998, Kulturowe sprzeczności kapitalizmu, tłum. Stefan Amsterdamski, Wydawnictwo Naukowe PWN, Warszawa.

Berger Peter L., 1995, Rewolucja kapitalistyczna. Pięćdziesiąt tez o dobrobycie, równości i wolności, tłum. Zygmunt Simbierowicz, Oficyna Naukowa, Warszawa.

Castells Manuel, 1982, Kwestia miejska, tłum. Bohdan Jałowiecki, Jacek Piątkowski, Państwowe Wydawnictwo Naukowe, Warszawa.

Davis Mike, 2009, Planeta slumsów, tłum. Katarzyna Bielińska, Instytut Wydawniczy Książka i Prasa, Warszawa.

Davis Mike, 1990, City of Quartz: Excavating the Future in Los Angeles, Vintage, London.

Dobbs Richard i in., 2012, Urban World: Cities and the Rise of the Consuming Class, Report McKinsey Global Institute (http://www.mckinsey.com/global-themes/urbanization/urban-worldcities-and-the-rise-of-the-consuming-class).

Donald Betsy, Glasmeier Amy, Gray Mia, Labao Linda, 2014, Austerity in the City: Economic Crisis and Urban Service Decline?, „Cambridge Journal of Regions, Economy and Society”, t. 7, s. 3-15.

Downs Anthony, 1961, Metropolitan Growth and Future Problems, „Land Economics”, t. 37, s. 311-320 .

Dymnicka Małgorzata, 2011, Kulturowe wytwarzanie przestrzeni publicznych, „Przegląd Socjologiczny”, t. 60 , nr 2-3.

Galor Zbigniew i in. (red.), 2014, Życie na skraju - marginesy społeczne wielkiego miasta, Societas Pars Mundi Publishing, Bielefeld.

Giddens Anthony, 2007, Socjologia, tłum. Alina Szulżycka, Wydawnictwo Naukowe PWN, Warszawa.

Gieryn Thomas F., 2000, A Space for Place in Sociology, „Annual Review of Sociology”, t. 26, s. 463 -496 .

Harman Chris, 2011, Kapitalizm zombi. Globalny kryzys i aktualność myśli Marksa, tłum. Hanna Jankowska, Muza, Warszawa.

Harvey David, 2003, The New Imperialism, Oxford University Press, Oxford.

Harvey David, 2012a, Bunt miast. Prawo do miasta i miejska rewolucja, tłum. Praktyka Teoretyczna, Fundacja Bęc Zmiana, Warszawa.

Harvey David, 2012b, Bunt miast. Z Davidem Harveyem rozmawia Michat Sutowski, „Dziennik Opinii. Krytyka Polityczna" (http://www.krytykapolityczna.pl/Wywiady/HarveyBuntmiast2/menu id-94.html [20.05.2016]).

Harvey David, 2014, Seventeen Contradictions and The End of Capitalism, Profile Books, London.

Häußermann Hartmut, Kronauer Martin, Siebel Walter (red.), 2004, An den Rändern der Städte. Armut und Ausgrenzung, Suhrkamp, Frankfurt am Main. 
Heath Joseph, Potter Andrew, 2010, Bunt na sprzedaż. Dlaczego kultury nie da się zagłuszyć, tłum. Hanna Jankowska, Muza, Warszawa.

Husson Michel, 2011, Kapitalizm bez znieczulenia. Studia nad wspótczesnym kapitalizmem, kryzysem światowym i strategia antykapitalistyczna, tłum. Zbigniew Marcin Kowalewski, Instytut Wydawniczy Książka i Prasa, Warszawa.

Jałowiecki Bohdan, Łukowski Wojciech, 2007, Przedmowa, w: Bohdan Jałowiecki, Wojciech Łukowski (red.), Gettoizacja polskiej przestrzeni miejskiej, Scholar, Warszawa.

Jasiński Artur, 2009, Wielkomiejski dylemat — przestrzeń publiczna czy przestrzeń bezpieczna, „Przestrzeń i Forma", nr 12, s. 319-352.

Jones Paul, 2009, Putting Architecture in Its Social Place: A Cultural Political Economy of Architecture, „Urban Studies”, t. 46, s. 2519-2536.

Krajewski Marek, 2010, Dyskretna niezgoda. Opór i kultura materialna, „Kultura Współczesna”, nr 2.

Kuryłowicz Ewa, 2008, Miasto jako przedmiot badań architektury, w: Bohdan Jałowiecki (red.), Miasto jako przedmiot badań naukowych w początkach XXI wieku, Scholar, Warszawa.

Lees Loretta, Slater Tom, Wyly Elvin, 2008, Gentrification, Routledge, New York-London.

Lefebvre Henri, 2012, Prawo do miasta, tłum. Ewa Majewska, Łukasz Stanek, „Praktyka Teoretyczna", nr 5.

Lordon Frédéric, 2012, Kapitalizm, niewola i pragnienie. Marks i Spinoza, tłum. Magdalena Kowalska, Michał Kozłowski, Instytut Wydawniczy Książka i Prasa, Warszawa.

Marks Karol, 1949, Wojna domowa we Francji, w: Karol Marks, Engels Fryderyk, Dzieła wybrane, t. 1, Książka i Wiedza, Warszawa.

May Tim, Beth Perry, Patrick Le Galès, Saskia Sassen, Mike Savage, 2005, The Future of Urban Sociology, „Sociology”, t. 39, s. 343-370.

Merrifield Andy, 2016, Nowa kwestia miejska, tłum. Piotr Juskowiak, Wydawnictwo Naukowe PWN, Warszawa.

Nawratek Krzysztof, 2008, Miasto jako idea polityczna, Korporacja Ha!art, Kraków.

Odrowąż-Coates Anna, 2015, A Gated Community as a Soft and Gendered Total Institution, „International Sociology", t. 30, s. 233-249.

Osajda Konrad, 2009, Nacjonalizacja i reprywatyzacja, Wydawnictwo C.H. Beck, Warszawa.

Ossowski Stanisław, 1967, Dzieła, t. 3: Z zagadnień psychologii społecznej, Państwowe Wydawnictwo Naukowe, Warszawa.

Pløger John, 2010, Contested Urbanism: Struggles about Representations, „Space and Polity”, t. 14, s. $143-165$.

Putnam Robert D., 2008, Samotna gra w kręgle. Upadek i odrodzenie wspólnot lokalnych w Stanach Zjednoczonych, tłum. Przemysław Sadura, Sebastian Szymański, Wydawnictwa Akademickie i Profesjonalne, Warszawa.

Rosanvallon Pierre, 2011, Kontrdemokracja. Polityka $w$ dobie nieufności, tłum. Agata Czarnacka, Wydawnictwo Naukowe Dolnośląskiej Szkoły Wyższej, Wrocław.

Sałustowicz Piotr, 2008, Miasto jako przedmiot badań polityki społecznej, w: Bohdan Jałowiecki (red.), Miasto jako przedmiot badań naukowych w poczattkach XXI wieku, Scholar, Warszawa.

Sassen Saskia, 2000, New Frontiers Facing Urban Sociology at the Millennium, „British Journal of Sociology", t. 51, s. 143-159.

Sennett Richard, 2009, Upadek człowieka publicznego, tłum. Hanna Jankowska, Muza, Warszawa.

Sztompka Piotr, 2005, Socjologia zmian społecznych, tłum. Jacek Konieczny, Wydawnictwo Znak, Kraków.

Tittenbrun Jacek, 2014, Kolonizacja nauki i świata przez kapitat. Teoria światów równoległych $w$ wydaniu socjologii wiedzy, Zysk i S-ka, Poznań.

Tobiasz-Lis Paulina, 2011, Osiedla grodzone $w$ Łodzi. Przyczyny i konsekwencje zjawiska, „Space - Society - Economy", nr 10. 
Touraine Alain, 2010, O socjologii, tłum. Michał Warchala, Wydawnictwo Naukowe PWN, Warszawa.

Touraine Alain, 2011, Myśleć inaczej, tłum. Maciej Byliniak, Państwowy Instytut Wydawniczy, Warszawa.

Touraine Alain, 2013, Po kryzysie, tłum. Marcin Frybes, Oficyna Naukowa, Warszawa.

Urbański Jarosław, 2014, Prekariat i nowa walka klas. Przeobrażenia wspótczesnej klasy pracowniczej i jej forma walki, Instytut Wydawniczy Książka i Prasa, Warszawa.

Wacquant Loïc, 2012, Trzy kroki w stronę historycznej antropologii faktycznie istniejącego neoliberalizmu, tłum. Agnieszka Kowalczyk, Krystian Szadkowski, „Praktyka Teoretyczna”, nr 5.

Wacquant Loïc, 2009, Więzienia nędzy, tłum. Michał Kozłowski, Instytut Wydawniczy Książka i Prasa, Warszawa.

Walton John, 1993, Urban Sociology: The Contribution and Limits of Political Economy, „Annual Review of Sociology", t. 19, s. 301-320.

Zaborska Katarzyna, 2007, Przestrzeń miejska — dobro wspólne czy ziemia niczyja?, w: Bohdan Jałowiecki, Wojciech Łukowski (red.), Gettoizacja polskiej przestrzeni miejskiej, Scholar, Warszawa.

\section{THE CRISIS OF CAPITALIST SOCIETY AND THE (NEW) URBAN QUESTION}

\section{Summary}

This article addresses the problem of the crisis of capitalist society, as described by Alain Touraine, through the example of urban space. It attempts to trace the symptoms of the crisis in the context of the urban question, understood as the set of (potential or actual) dysfunctional consequences of the organization of social life in accord with individual and/or collective expectations within the sphere of the city.

\section{Key words / słowa kluczowe}

capitalist society / społeczeństwo kapitalistyczne; urban question / kwestia miejska; social movements / ruchy społeczne; public space / przestrzeń publiczna; privatization of life / prywatyzacja życia 